\title{
Activated carbon by co-pyrolysis and steam activation from particle board and melamine formaldehyde resin: production, adsorption properties and techno economic evaluation
}

\author{
Kenny Vanreppelen ${ }^{1,2}$, Sonja Schreurs ${ }^{1,2}$, Tom Kuppens ${ }^{3}$, Theo Thewys $^{3}$, Robert \\ Carleer $^{2}$, Jan Yperman \\ ${ }^{1}$ Research group $\mathrm{NuTeC}$ \\ Department of Industrial Sciences and Technology - Engineering \\ XIOS Hogeschool Limburg, Diepenbeek, Belgium \\ e-mail: kenny.vanreppelen@xios.be \\ ${ }^{2}$ Research group of Applied and Analytical Chemistry, \\ Hasselt University,Diepenbeek, Belgium \\ ${ }^{3}$ Research group Environmental Economics and Law \\ Hasselt University, Diepenbeek, Belgium
}

Cite as: Vanreppelen, K. et.al., Activated carbon by co-pyrolysis and steam activation from particle board and melamine formaldehyde resin: production, adsorption properties and techno economic evaluation, J. sustain. dev. energy water environ. syst., 1(1), pp 41-57, 2013, http://dx.doi.org/10.13044/j.sdewes.2013.01.0004

\begin{abstract}
One of the top strategic objectives and research areas in Europe is recovering wood from processing and end of life products. However, there are still several 'contaminated' wood products that are not or only partly reused/recycled. Particle board waste which is contaminated with aminoplasts is one of these products. In addition, a considerable amount of aminoplast waste resinis produced for the production of particle board that cannot be re-used or recycled. The chemical properties of these wastes (high nitrogen content of $5.9 \mathrm{wt} \%$ and $54.1 \mathrm{wt} \%$ for particle board and melamine formaldehyde respectively) make them ideal precursors for the production of nitrogenised activated carbon. The profitability of the produced activated carbon is investigated by calculating the net present value, the minimum selling price and performing a Monte Carlo sensitivity analysis. Encouraging results for a profitable production are obtained even though the current assumptions start from a rather pessimistic scenario.
\end{abstract}

\section{KEYWORDS}

Particle Board, Melamine Formaldehyde, Economic Evaluation, Pyrolysis, Monte Carlo Sensitivity Analysis, Activated Carbon

\section{INTRODUCTION}

The world population has increased significantly since the start of the industrial revolution and thereby also the waste production and the depletion of the world's resources. In an ideal society there is no waste generation, however in today's society large quantities of waste cannot be eliminated. Improper management of this waste can lead to serious health threats as a result of fires, explosions, and contamination of air, soil, and water [1]. Sustainable management needs to reduce the amount of waste that is discharged to the environment. These advanced waste management systems include prioritized management strategies to minimize environmental problems and preserve resources [1]. In decreasing order of importance and with respect to the final disposition of the waste, these strategies are [1]: 
- Minimization or prevention of waste

- Recycling of waste

- Thermal treatment with energy recovery

- Land filling

It is thus necessary to search for new recycling/reengineering methods for waste products that are still landfilled or burned.

Recovering wood from processing and end of life products is recognised as one of the top strategic objectives and research areas in Europe [2]. This recovered wood provides a high volume resource for recycled products and new advanced materials, with further enhancing the environmental profile of wood [2]. One could say that, it is not necessary to maximize the utilisation of wood because it is the most abundant biodegradable and renewable material available on this planet [2]. However, there are numerous reasons to maximize its utilization like economic concerns, social preoccupation with the climate change and greenhouse gas emissions as well as threats to forests due to adverse effect of climate change, pollution abatement and efficient savings of fossil primary energy [2-4].

There are already different recycling and reengineering practices for clean wood like fuel briquettes, animal bedding, mulch, salvaged timber, recycling into particle board, etc. However there are still some wood products that are not or only partly reused/recycled. One of these products is particle board (PB) which is chemically contaminated with aminoplasts (melamine formaldehyde (MF), melamine urea formaldehyde (MUF) and urea formaldehyde). These products can be partly recycled in the production of 'new' PB; loss of mechanical properties of the final product will not allow to use significant quantities of board off-cuts and wood dust (chips between $3 \mathrm{~mm}-50 \mathrm{~mm}$ ) as an incoming wood stream $[2,5]$. In Australia for example the panel board off-cuts (on average $8 \%$ of the PB is wasted as off cuts) and wood streams contaminated with glues are currently not used [2]. In the UK $75 \%$ of the wood waste from the furniture industry consists of board off-cuts and sawdust [6]. In addition the produced furniture ends up eventually as waste. In the UK, the end of life furniture (board materials account for $80 \%$ in weight) is estimated between 1.9 and 2.2 Mtonnes [7]. The annual production of new PB in 2004 by the European PB industry was 34.3 million $\mathrm{m}^{3}$ [8].

Furthermore a considerable amount of aminoplast waste resin is produced for the production of particle board (PB) that cannot be re-used or recycled at this moment.

In addition, combustion of wood waste containing these aminoplasts resins might cause pollution because it results in the production of toxic gases like ammonia, isocyanic and hydrocyanic acid and nitrous oxides [9-13]. To avoid environmental problems and landfilling costs, and to turn this waste stream into a rather profitable material resource, a sustainable solution is mostly required [13].Based on the properties of the waste sources (e.g. PB and MF) the production of high value nitrogenised activated carbon (AC) is considered as a possible opportunity.

The aim of this work is to evaluate the profitability of $\mathrm{AC}$ production from $\mathrm{PB}$ and $\mathrm{MF}$ waste based on preliminary research results and an economic feasibility study before up scaling the research. For this purpose a process design and an economical model has been developed in a previous work [13]. After production of AC from different blends of $\mathrm{PB}$ and MF a low concentration phenol adsorption test has been carried out. Based on the obtained results, the Net Present Value (NPV) of the cash flows generated by an investment in an AC production facility and the minimum selling price of this $\mathrm{AC}$ has been calculated. The key variables for the profitability of the AC plant are identified. Finally, Monte Carlo sensitivity analysis is carried out to take uncertainties into account. 


\section{METHODOLOGY}

\section{Economical feasibility model}

The feasibility of the AC production facility is investigated by building a cost-benefit model (in EUR 2009) and a process design for estimating the total capital investment, the production costs, the possible revenues and the NPV based on various literature sources. This model is extensively detailed in ref.[13]. An overview of the economical strategy is presented in Fig. 1.

Investors use various investment criteria to evaluate the profitability of an investment before they want to invest. According to [14] the NPV is the best criterion for selecting or rejecting an investment, either industrial or financial. By using the NPV the expected profit is estimated using today's value of current and future cash flows generated by the AC production plant during a certain time period using a predetermined discount rate [15]. The NPV formula is given in Eq. 1:

$$
N P V=\sum_{n=1}^{T} \frac{C F_{n}}{(1+i)^{n}}-I_{0}
$$

With: T - life span of the reactor (20years[15-17]), $\mathrm{I}_{0}$ - initial total capital investment in year zero, $C_{n}-$ Cash Flows generated in year $n, i-$ discount rate is set at $9 \%$ incorporating the market interest rate and some risk premium[18].

The cash flow in a given year can be calculated by using Eq. 2[15,17]. It is the difference between revenues (R) and expenditure (E) after tax (t) generated by the investment taking depreciation into account because it lowers tax payments. To calculate the cash flow, depreciation (D) also needs to be taken into account because it lowers tax payments[15,17].

$$
C F_{n}=(1-t) *(R-E)+t * D
$$

All the results of the base case are based on an average operation time of the reactor of 7000 hours per year without shutdown due to maintenance; etc. ( $80 \%$ operating $+20 \%$ maintenance, etc.). In general, when the NPV is positive, the investment is a good decision.

The NPVs are only valid if the calculated revenues and expenses are $100 \%$ certain. Because all the different variables are the most likely values obtained from literature, these are prone to uncertainty. Monte Carlo sensitivity analysis is performed to have an idea about the impact of these uncertainties on the NPV. For each run of the simulation, a random value of all the uncertain variables is drawn following a presupposeddistribution resulting in a NPV. In this study 10000 runs are carried out using the @Risk software from Palisade Decision Tools. The total uncertainty of the NPV than can be explained by the corresponding range of values and the obtained distribution.

Finally, taking into account all these uncertainties the minimum selling price at which the AC should be sold in order to guarantee a 95\% chance on a positive NPV is calculated.

\section{Sample preparation}

The PB samples are prepared from industrial water-resistant PB panels (glued with MUF) which have been sawn to strips of $1 \mathrm{~cm}$ and then cut $(\leq 2.0 \mathrm{~mm})$ with a high-speed rotary cutting mill (Retsch SM 100). The provided waste samples of MF have particle 
size $\leq 2.0 \mathrm{~mm}$. For characterisation of the input materials they are further reduced in size by milling to $\leq 0.5 \mathrm{~mm}$ with a IKA Werke Yellow Line A10 mill. Prior to pyrolysis and characterisation the samples are oven dried $\left(110^{\circ} \mathrm{C}\right)$ and mixed.

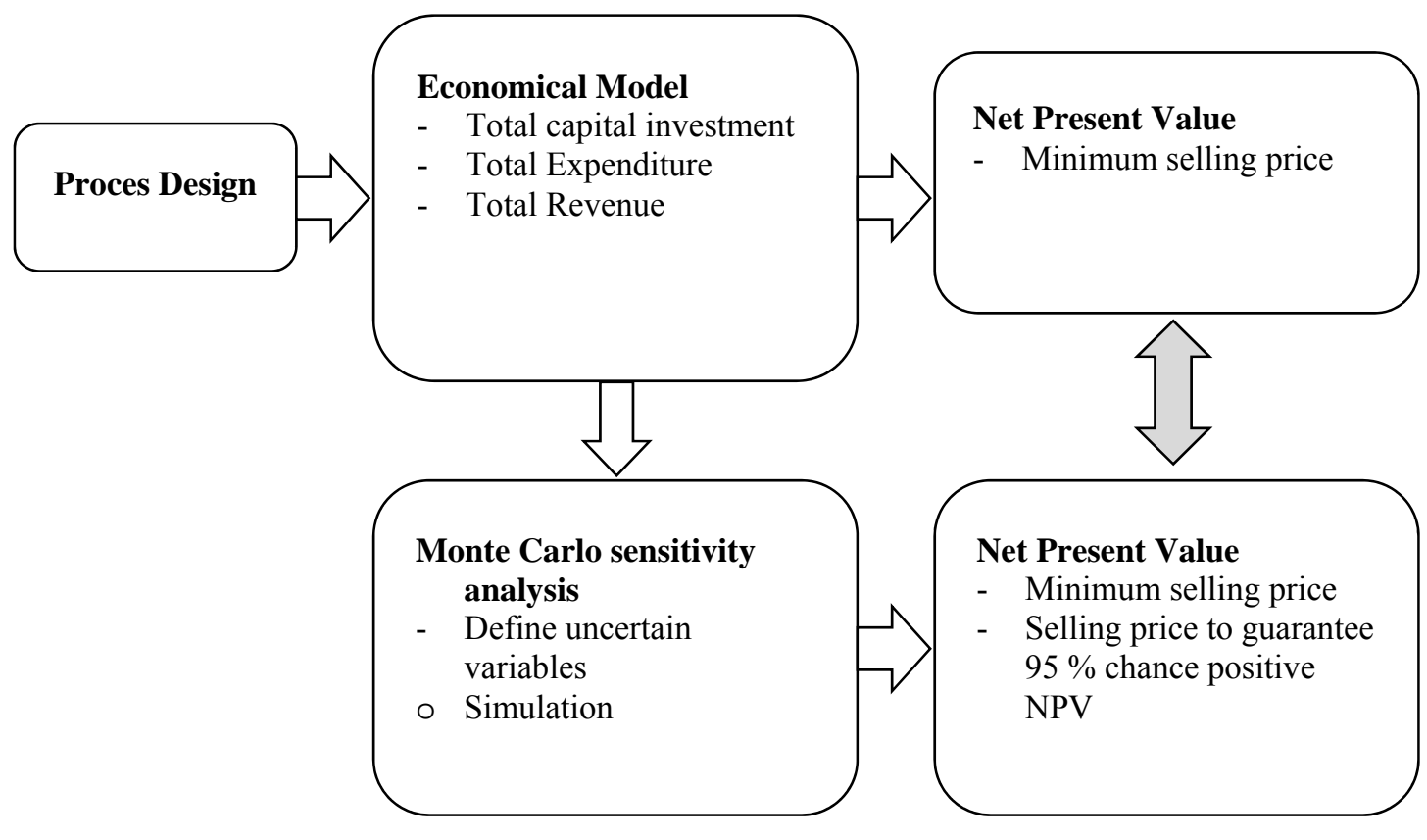

Figure 1.Economical strategy

\section{Characterisation of the input materials}

The PB and MF ratios are analysed by a DuPont Instruments 951 thermal analyser (TGA). The input materials are heated in inert atmosphere (with a $\mathrm{N}_{2}$-gasflow of 30 $\mathrm{ml} / \mathrm{min}$ ) from room temperature to $800{ }^{\circ} \mathrm{C}$ at a ramp of $20{ }^{\circ} \mathrm{C} / \mathrm{min}$ followed by an isothermal period of $10 \mathrm{~min}$, then heated to $900{ }^{\circ} \mathrm{C}$ at a ramp of $20{ }^{\circ} \mathrm{C} / \mathrm{min}$. The ash residue of the pure $\mathrm{PB}$ and $\mathrm{MF}$ are analysed by the TGA with the following temperature program: heating from room temperature to $800{ }^{\circ} \mathrm{C}$ at a ramp of $20^{\circ} \mathrm{C} / \mathrm{min}$ in $\mathrm{N}_{2}$-flow $(30$ $\mathrm{ml} / \mathrm{min}$ ), then $10 \mathrm{~min}$ isothermal in $\mathrm{O}_{2}$-flow $(30 \mathrm{ml} / \mathrm{min})$, heating to $900{ }^{\circ} \mathrm{C}$ at a ramp of $20^{\circ} \mathrm{C} / \mathrm{min}$ in $\mathrm{O}_{2}$-flow $(30 \mathrm{ml} / \mathrm{min})$. The elemental composition $(\mathrm{C}, \mathrm{H}, \mathrm{N}, \mathrm{S})$ of the samples is analysed by a Thermo ElectronFlashEA1112 elemental analyzer. BBOT (2,5-bis (5-tert-butyl-benzoxazol-2-yl) thiophene) is used to calibrate the instrument. Oxygen is determined by difference.

\section{Preparation of the activated carbon}

The waste blends $(2 \mathrm{~g}-5 \mathrm{~g})$ are pyrolysedin triplicatein a horizontal quartz tube reactor (Nabertherm), with a heating rate of $20^{\circ} \mathrm{C} / \mathrm{min}$ from room temperature to $800{ }^{\circ} \mathrm{C}$ under nitrogen atmosphere $(30 \mathrm{ml} / \mathrm{min})$ followed by a $30 \mathrm{~min}$ isothermal activation under steam atmosphere (water flow of $2 \mathrm{ml} / \mathrm{h}$ direct injected in the reactor). The produced gases are combusted.

\section{Batch adsorption experiments}

The phenol adsorption of the different ACs against a commercial AC (Norit GAC 1240) were evaluated by introducing $50 \mathrm{ml}$ of a $100 \mathrm{ppm}$ unbuffered phenol solution with 
different quantities of $\mathrm{AC}$ in a hermetically closed flask. The phenol was of analytical grade and Milli-Q Millipore water $(18.2 \mathrm{M} \Omega / \mathrm{cm}$ conductivity) was used. The flasks where placed in a thermostatic water bath $\left(25^{\circ} \mathrm{C}\right)$ and stirred for $24 \mathrm{~h}$. It is assumed that equilibrium is reached in this time period. The solution was filtered and the residual phenol concentration was analysed using a Pharmacia Biotech Ultraspec 2000 UV-VIS spectrophotometer at $270 \mathrm{~nm}$. Calibration is carried out using a number of phenol standard solutions(concentration range: blank, 1 ppm, 5 ppm, 10 ppm, 30 ppm, 50 ppm, $80 \mathrm{ppm}$ and $100 \mathrm{ppm}$ ). Each experiment was done in quadruplicate, with an average scatter in the results of $5 \%$.

\section{RESULTS AND DISCUSSION}

\section{Characterisation of the input material}

The thermal behaviour of $\mathrm{PB}$ and MF is investigated by TGA-analysis in $\mathrm{N}_{2}$-atmosphere. In the literature, limited information is provided concerning the thermal degradation of the MF. The TG and DTA curves of PB and MF (Fig. 2) show respectively a small weight loss of $2 \mathrm{wt} \%$ and $3 \mathrm{wt} \%$ because of fixed moisture $\left(25-150{ }^{\circ} \mathrm{C}\right)$ followed by a major weight loss step. For PB this corresponds to the degradation of hemicellulose, cellulose and lignin and can be observed from $194{ }^{\circ} \mathrm{C}-385^{\circ} \mathrm{C}$ (weight loss of $62 \mathrm{wt} \%$ ), followed by a further slow degradation until a fixed carbon content of $13 \mathrm{wt} \%$ (at $800{ }^{\circ} \mathrm{C}$ ). For MF a small loss $(5 \mathrm{wt} \%)$ is observed from $125^{\circ} \mathrm{C}$ till $372{ }^{\circ} \mathrm{C}$. Girods et al. [12] found mainly N-compounds such as isocyanic acid and ammonia as degradation products below $350{ }^{\circ} \mathrm{C}$. Additionally a loss of $35 \mathrm{wt} \%$ (between $372{ }^{\circ} \mathrm{C}-$ $424{ }^{\circ} \mathrm{C}$ and) is observed with a maximum degradation rate at $400{ }^{\circ} \mathrm{C}$. In this temperature range the detected degradation products are formaldehyde, methanol, amine, ammonia and sublimated melamine[12]. In the temperature range starting at $424{ }^{\circ} \mathrm{C}$ the resin undergoes extensive degradation. Devallencourt et al.[19] assumed that the resin progressively deaminates forming cyameluric structures in the range of $410{ }^{\circ} \mathrm{C}-525^{\circ} \mathrm{C}$ with evaporation of $\mathrm{HCN}$ and $\mathrm{CH}_{3} \mathrm{CN}$. Above $660^{\circ} \mathrm{C}$ the $\mathrm{MF}$ resin undergoes extensive degradation with production of $\mathrm{HCN}, \mathrm{CO}, \mathrm{CO}_{2}$ [19]. Fixed carbon content at $800^{\circ} \mathrm{C}$ of $11 \mathrm{wt} \%$ is obtained. 


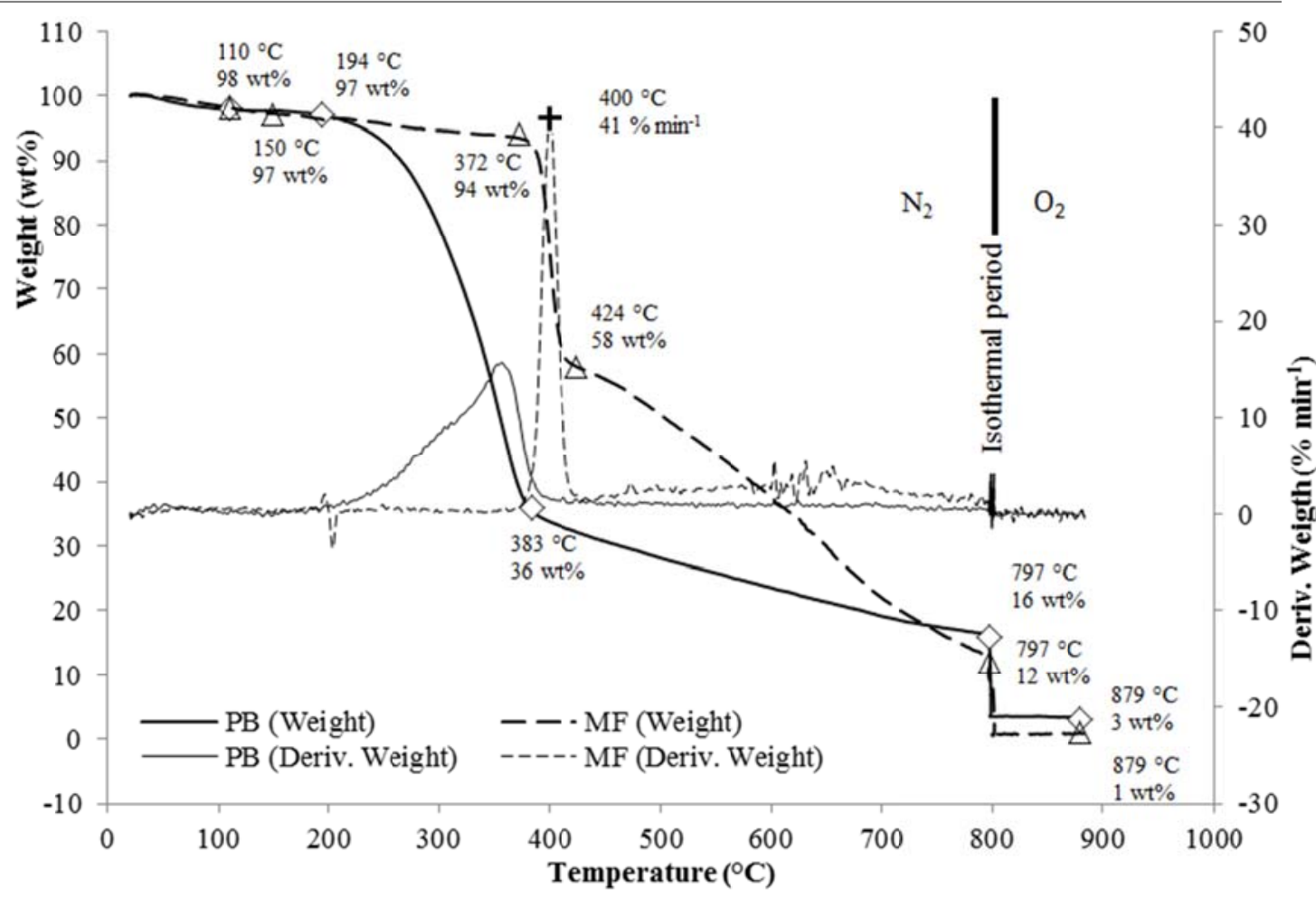

Figure 2. TGA of PB (full line) and MF (dashed line)

Ultimate analysis is carried out on the pure products and is presented in Table 1 . The chemical properties i.e. the high nitrogen content of PB (5.9 wt \%) and MF (54.1 wt \%) waste materials indicate that pyrolysis and subsequent activation will result in in-situ production of nitrogenised ACs.

Table 1. Ultimate analysis

\begin{tabular}{lll}
\hline & PB - MF (5/0) & PB - MF (0/5) \\
\hline $\begin{array}{l}\text { Ultimate analysis } \\
\text { (\%)(dry and ash free) }\end{array}$ & \\
C & $46 \pm 3$ & $37.2 \pm 0.4$ \\
N & $5.9 \pm 0.4$ & $54.1 \pm 0.6$ \\
H & $5.9 \pm 0.4$ & $4.7 \pm 0.04$ \\
S & $0.9 \pm 0.4$ & $0 \pm 0$ \\
O* & $41 \pm 4$ & $4 \pm 1$ \\
N/C molar ratio & 0.13 & 1.45 \\
O/C molar ratio & 0.89 & 0.11 \\
\hline \multicolumn{2}{l}{ "Calculated by difference }
\end{tabular}

\section{Pyrolysis and activation experiments}

Pyrolysis and steam activation is performed on different blends of PB and MF resin. The effect on the product distribution is shown in Table 2. An average char yield of 27 $\mathrm{wt} \%$ is obtained after pyrolysis. The mix ratio $\mathrm{PB}-\mathrm{MF}$ has no effect on the char yield. For the successive range of ratios $[\mathrm{PB}-\mathrm{MF}(5 / 0) \rightarrow \mathrm{PB}-\mathrm{MF}(2 / 3)]$, the char yield is lower than predicted in Vanreppelen et al. [13]. In the case of PB - MF (1/4) a higher yield is observed. It can be seen that the resulting $\mathrm{AC}$ yield after activation decreased in 
the successive range [PB - MF (5/0) $\rightarrow$ PB - MF (1/4)] with a burn-off between 18.5 $\mathrm{wt} \%$ and $59 \mathrm{wt} \%$. Nevertheless, the char yields are lower (with exception of PB - MF (1/4)) than predicted in Vanreppelen et al. [13] and higher AC yields are achieved for all the ratios except for the pure $\mathrm{PB}$ which is somewhat lower.

The chemical composition of the produced ACs with their standard deviations is given in Table 2. By increasing the fraction of MF in the mixture a significant higher $\mathrm{N}$-content is obtained with an increase of $84 \%$ from $2.2 \mathrm{wt} \%$ to $14 \mathrm{wt} \%$.

Table 2. AC yield and ultimate analysis

\begin{tabular}{|c|c|c|c|c|c|}
\hline & $\begin{array}{c}\text { PB - MF } \\
(5 / 0)\end{array}$ & $\begin{array}{c}\text { PB - MF } \\
(4 / 1)\end{array}$ & $\begin{array}{c}\text { PB - MF } \\
(3 / 2)\end{array}$ & $\begin{array}{c}\text { PB - MF } \\
(2 / 3)\end{array}$ & $\begin{array}{c}\text { PB - MF } \\
(1 / 4)\end{array}$ \\
\hline \multicolumn{6}{|c|}{ Pyrolysis products (wt\%) } \\
\hline - char & $27 \pm 0.5$ & $28 \pm 0.3$ & $28 \pm 0.7$ & $26 \pm 0.9$ & $27 \pm 0.9$ \\
\hline - gases & 73 & 72 & 72 & 74 & 73 \\
\hline \multicolumn{6}{|l|}{ Activation (wt\%) } \\
\hline - activated carbon & $22 \pm 0.4$ & $21 \pm 0.7$ & $19 \pm 0.6$ & $15 \pm 0.9$ & $11 \pm 0.6$ \\
\hline$\%$ burn-off & 18.5 & 25 & 32 & 42 & 59 \\
\hline - gases & 78.0 & 78.6 & 80.7 & 84.7 & 89.1 \\
\hline \multicolumn{6}{|c|}{$\begin{array}{l}\text { Ultimate analysis (\%) (dry } \\
\text { and ash free) }\end{array}$} \\
\hline C & $91 \pm 1$ & $85 \pm 4$ & $86 \pm 2$ & $83 \pm 2$ & $83.4 \pm 0.7$ \\
\hline $\mathbf{N}$ & $2.24 \pm 0.04$ & $4.3 \pm 0.2$ & $7.35 \pm 0.07$ & $9.6 \pm 0.3$ & $14 \pm 1$ \\
\hline $\mathbf{H}$ & $1.14 \pm 0.06$ & $1.32 \pm 0.06$ & $1.3 \pm 0.1$ & $1.5 \pm 0.2$ & $1.65 \pm 0.08$ \\
\hline $\mathbf{S}$ & $0.1 \pm 0.1$ & $0.07 \pm 0.01$ & $0 \pm 0$ & $0 \pm 0$ & $0 \pm 0$ \\
\hline $\mathbf{O}^{*}$ & $6 \pm 1$ & $8 \pm 4$ & $6 \pm 2$ & $6 \pm 3$ & $1.4 \pm 0.8$ \\
\hline N/C atomic ratio & 0.02 & 0.05 & 0.09 & 0.12 & 0.17 \\
\hline $\mathrm{O} / \mathrm{C}$ atomic ratio & 0.07 & 0.09 & 0.07 & 0.07 & 0.02 \\
\hline
\end{tabular}

Calculated by difference

\section{Low concentration phenol adsorption}

Phenol is an important raw material and/or product of the chemical and allied industries [20]. Phenol and phenolic compounds are very toxic with a fixed low admissible level following the Flemish regulation of $0.1 \mathrm{mg} / \mathrm{l}$ of surface water for the production of drinking water, $\leq 0.05 \mathrm{mg} / 1$ of surface swimming water and $0.5 \mathrm{mg} / \mathrm{lof}$ groundwater [21]. It is well known that ACs containing nitrogen-containing surface groups, have a basic nature and thus have enhanced adsorption capacity toward phenol [22]. To evaluate the performance of the produced AC, phenol adsorption tests have been performed.

The effect of the adsorbent dosage on the phenol removal against a commercial AC is shown in Fig. 3. It can be seen that the performance of AC PB - MF (5/0 \& 4/1) are similar but somewhat lower than the commercial AC. At anadsorbent dosage of $0.1 \mathrm{~g}$, phenol removal efficiency for all the produced carbons is higher than $90 \%$.

When combining Fig. 3 and Table 2 no correlation can be found with the incorporated $\mathrm{N}$. This is probably due to a decrease of surface area by blocking of pores [23-25]. 


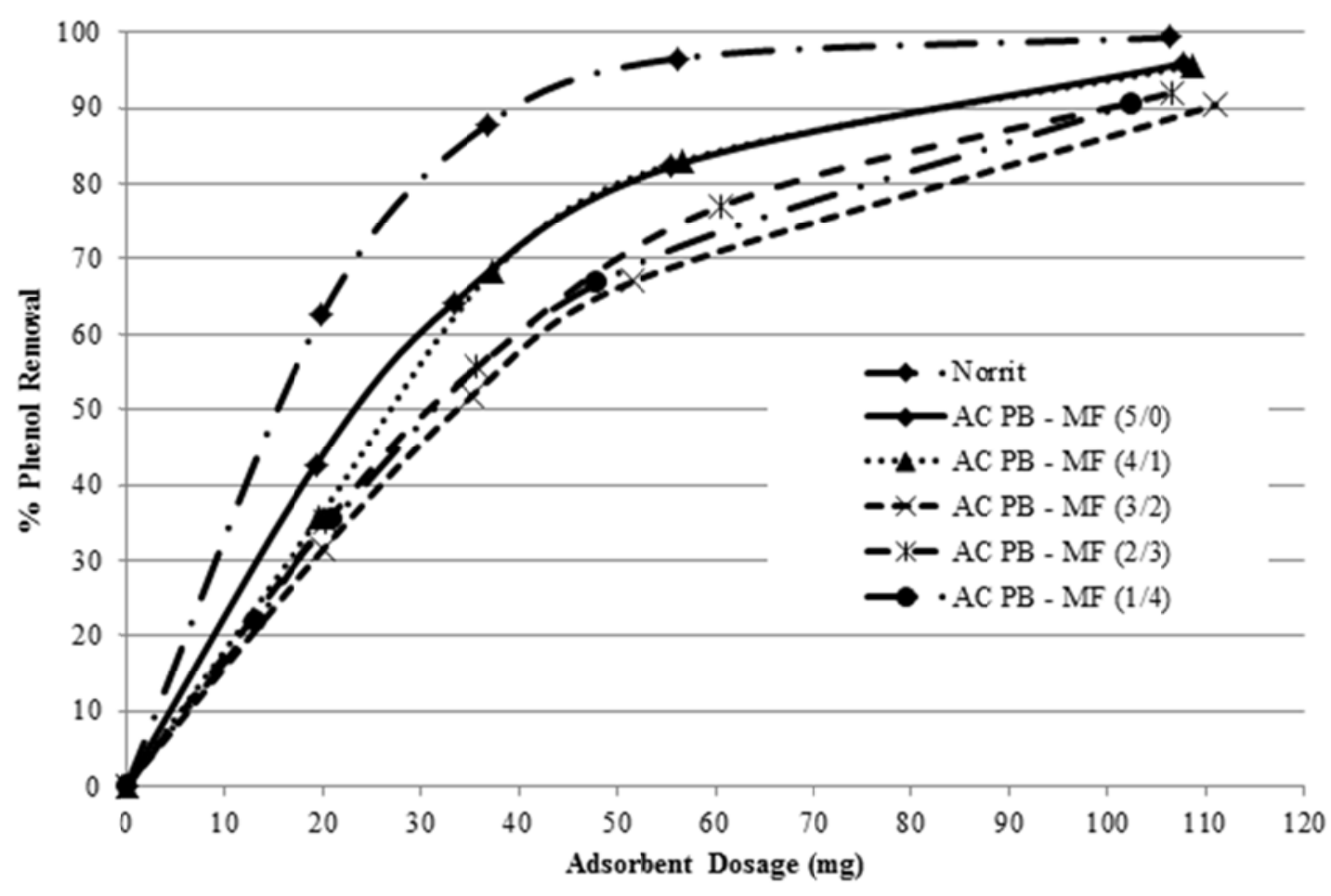

Figure 3. Effect of adsorbent dosage

\section{Economic evaluation base case}

Based on theeconomical model and process design proposed by Vanreppelen et al. [13] the total capital investment is estimated by using the Percentage of Delivered-Equipment cost method and various literature sources. The pyrolysis and activation reactor are calculated as a first plant cost. The total expenditure consists of two parts, namely the operating cost and the yearly interest payments. It is assumed that the investment is financed by means of a loan with a yearly interest of $4.0 \%$. The operation costs are divided into the following categories: maintenance, insurance, overhead, labour, nitrogen gas, delivered feed, energy and water costs which are generally expressed as a percentage of the total fixed-capital investment for the first three $[13,15,26]$. Table 3 provides a guideline for the calculation of the annual operating costs for the all eight items. In this model, a gate fee of $70 \mathrm{EUR} / \mathrm{t}$ [22] for processing the PB waste is paid. In Belgium a MF factory pays $220 \mathrm{EUR} / \mathrm{t}$ for disposing its waste to a landfill site (including transport) [13]. However in this model the cost for MF is set at $0 \mathrm{EUR} / \mathrm{t}$ to have a worst case scenario.

Table 3. Guideline for calculating the annual operating costs (from ref [13])

\begin{tabular}{ll}
\hline \multicolumn{2}{l}{ Annual operating costs } \\
\hline Maintenance & $3 \%$ of Fixed-capital investment \\
Overhead & 2\% of Fixed-capital investment \\
Insurance & \% of Fixed-capital investment \\
Labour costs & Labour costst $=$ Total staff members (rounded up) $* 55 \mathrm{kEUR} \mathrm{year}^{-1}$ \\
& Totalstaffmembers $=1.04 *\left(\left[1+Y_{\text {char }}\right] * Q_{\text {feedinputpyrolysis }}\right)^{0.475} * 3$ shifts \\
Delivered feed & dependent on the mix ratio \\
cost & per ton input material $15 \mathrm{~m}^{3}$ with a price of $1.5 \mathrm{EUR} / \mathrm{m}^{3}$ \\
Water &
\end{tabular}


- Power $1 \mathrm{t} / \mathrm{h}$ facility theelectricity consumption is $160 \mathrm{~kW}$ with a price of 0.0725 $\mathrm{EUR} / \mathrm{kWh}$ provided by combustion of the gases

- Heat

Nitrogen gas $8 \mathrm{~kg}$ nitrogen gas per ton input materiala cost of $2.5 \mathrm{EUR} / \mathrm{kg}$

NPVs have been calculated for different blends of PB and MF resin waste for a processing capacity of $1 \mathrm{t} / \mathrm{h}$. These different ratios result in different yields (see Table 2), different qualities and hence different costs are incurred. The total capital investment and the total expenditure for this facility are displayed in Table 4. The total capital investment is about the same for every facility except for the pure MF resin ( $\mathrm{PB}-\mathrm{MF} 0 / 5$ ). Compared to the predicted values in Vanreppelen et al. [13], the lower char yields (with exception of $\mathrm{PB}-\mathrm{MF}(1 / 4)$ ) result in a lower total capital investment than predicted in Vanreppelen et al. [13]. There is a very little difference in the sum of the operating costs and the yearly interest payments for all the ratios. Due to the gate fee from the delivered feed, the total expenditure cost decreases with a decrease of MF in the mixture. The total expenditure is similar to the total investment cost and is lower than predicted with exception of the PB - MF (1/4) ratio. The corresponding NPVs for selling prices between $1 \mathrm{kEUR} / \mathrm{t}$ and $4.5 \mathrm{kEUR} / \mathrm{t}$ are presented in Fig. 4. The minimum selling price (NPV $=0$ EUR) of the produced AC can be found in Fig. 4 and Table 4. Fig 5 shows the discounted cumulative cash flow of an AC production facility operating at $1 \mathrm{t} / \mathrm{h}$ and a selling price of $2.5 \mathrm{kEUR} / \mathrm{t}$. With increasing share of MF the minimum selling price increases from 1.6 kEUR t ${ }^{-1}$ until $3.9 \mathrm{kEUR} / \mathrm{t}$. Girods et al. [22] estimated the selling price of AC from PB ( $\mathrm{N}$-content $1.5 \mathrm{wt} \%-2 \mathrm{wt} \%$ ) to be around $2.0 \mathrm{kEUR} / \mathrm{t}$. They state that by optimising their activation conditions a higher $\mathrm{N}$-content could be obtained and hence yield a higher quality (better adsorption properties) and thus yield a higher value.

Table 4. Total capital investment, annual expenditure and minimum selling price for the production of $\mathrm{AC}$

\begin{tabular}{|c|c|c|c|c|c|}
\hline & \multicolumn{5}{|c|}{ PB - MF ratio } \\
\hline & $5 / 0$ & $4 / 1$ & $3 / 2$ & $2 / 3$ & $1 / 4$ \\
\hline Total capital investment & 10,420 & 10,503 & 10,572 & 10,455 & 10,605 \\
\hline & kEUR & kEUR & kEUR & kEUR & kEUR \\
\hline Expenditure & & & & & \\
\hline $\begin{array}{l}\text { - Gate fee delivered } \\
\text { feed }\end{array}$ & $490 \mathrm{kEUR}$ & 392 kEUR & $330 \mathrm{kEUR}$ & 196 kEUR & $98 \mathrm{kEUR}$ \\
\hline $\begin{array}{l}\text { - Operating cost }+ \\
\text { yearly interest }\end{array}$ & 1,581 kEUR & 1,586 kEUR & 1,589 kEUR & 1,573 kEUR & $\begin{array}{l}1,579 \\
\mathrm{kEUR}\end{array}$ \\
\hline - Total & 1,091 kEUR & 1,194 kEUR & 1,295 kEUR & 1,377 kEUR & $\begin{array}{l}1,481 \\
\mathrm{kEUR}\end{array}$ \\
\hline Minimum selling price & $1.6 \mathrm{kEUR} / \mathrm{t}$ & $1.8 \mathrm{kEUR} / \mathrm{t}$ & $2.0 \mathrm{kEUR} / \mathrm{t}$ & $2.6 \mathrm{kEUR} / \mathrm{t}$ & $\begin{array}{l}3.9 \\
\mathrm{kEUR} / \mathrm{t}\end{array}$ \\
\hline
\end{tabular}

Vanreppelen et al. [13] expect that optimized AC from PB could yield a selling price of maximum $2.5 \mathrm{kEUR} / \mathrm{t}$. When looking at Fig. 4, Fig. 5 and Table 4 in the interval 2.0 $\mathrm{kEUR} / \mathrm{t}-2.5 \mathrm{kEUR} / \mathrm{t}$ only the ratios where the share of PB is greater than the share of MF are profitable. For example the pure PB would yield a NPV of the cash flows of 3.6 MEUR - 8.4 MEUR when the product is sold at a price of $2.0 \mathrm{kEUR} / \mathrm{t}$ and $2.5 \mathrm{kEUR} / \mathrm{t}$ 
respectively. The payback time for this $\mathrm{AC}$ production facility is 11 and 7 years respectively.

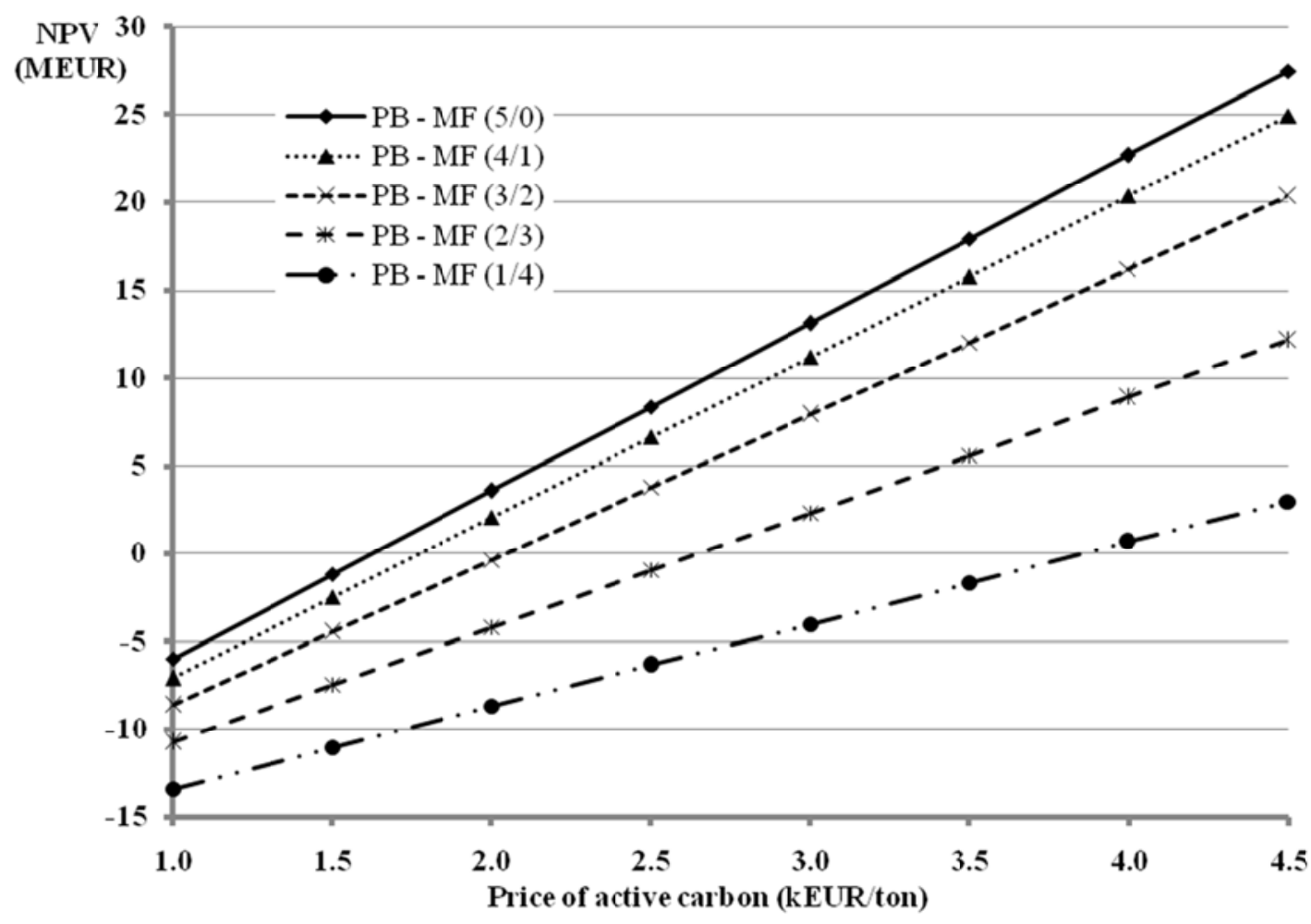

Figure 4. NPV for a $1 \mathrm{t} / \mathrm{h}$ production facility

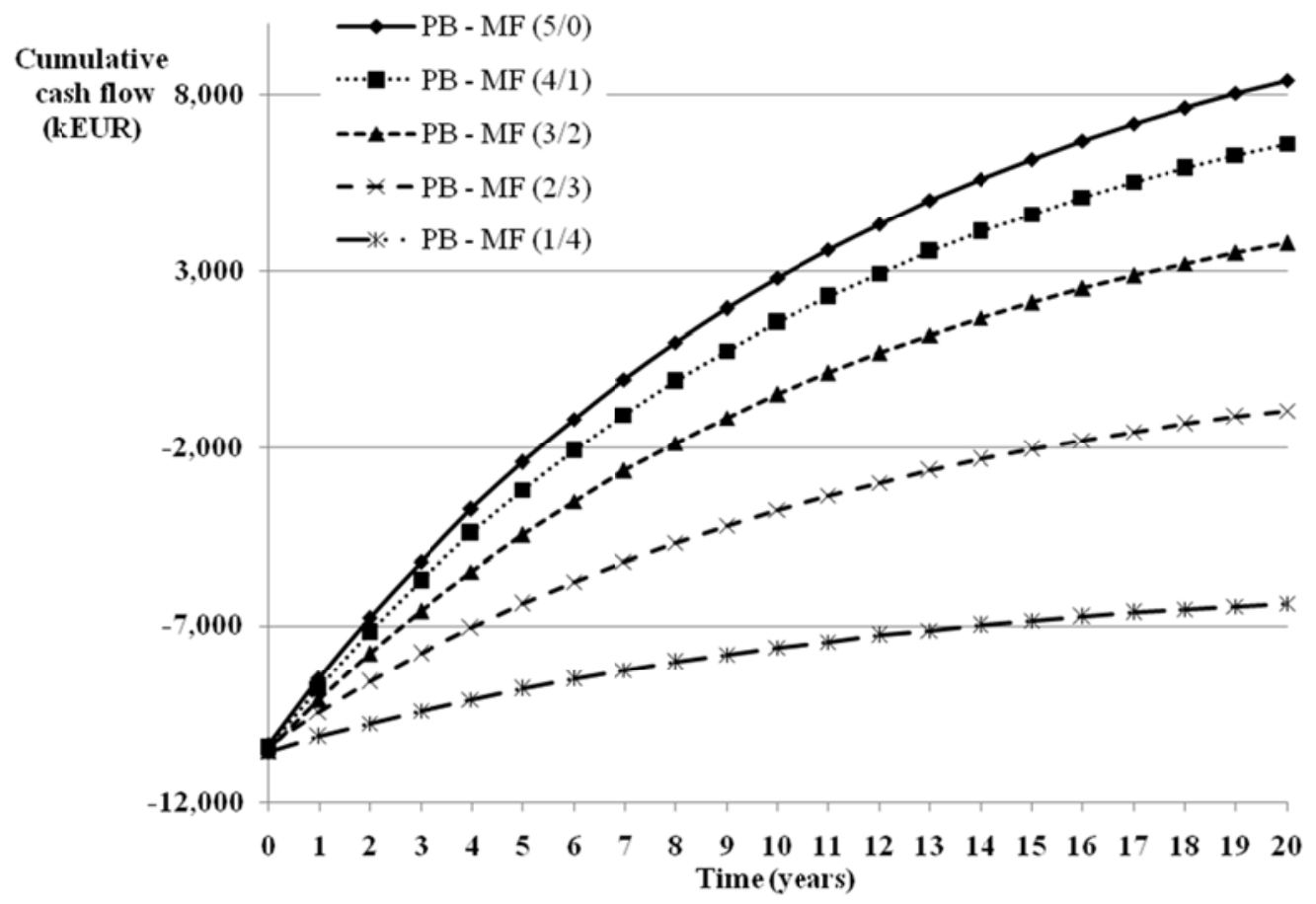

Figure 5. Payback time for a $1 \mathrm{t} / \mathrm{h}$ production facility at a selling price of $2.5 \mathrm{kEUR} / \mathrm{t}$ 


\section{Economic impact of the gate fee for MF}

By combining the previous economic analysis, the AC yields from Table 2 and the preliminary phenol adsorption test (Fig. 3) one could argue that it is only useful to study the pure PB. Moreover, the possible gate fee from the MF waste needs to be considered. The minimum gate fee for MF waste needs to be calculated to match at least the NPV of $\mathrm{AC}$ from PB (3.6 MEUR at a selling price of $2.0 \mathrm{kEUR} / \mathrm{t}$ ).

When a gate fee of $180 \mathrm{EUR} / \mathrm{t}$ is paid for processing the MF waste, the $\mathrm{PB}-\mathrm{MF}(4 / 1)$ mix ratio is economical at least equally attractive as the $\mathrm{AC}$ from pure $\mathrm{PB}$. Taking the landfill cost into account, a MF production facility is already satisfied to pay less than 220 EUR/t. In addition two waste streams are reused and so the value of the AC production facility is enhanced.

\section{Economic impact of the nitrogen content}

Recent literature $[13,22,27,28]$ states that nitrogen incorporation is a key parameter for the adsorption properties of AC, especially for the removal of acid gases and phenolic compounds. Such a nitrogenised AC could yield a very high selling price (as high as 4 $\mathrm{kEUR} / \mathrm{t}-6 \mathrm{kEUR} / \mathrm{t}$ ) as discussed in [13]. When looking at the $\mathrm{N}$ incorporation (Table 2) in the produced AC, high $\mathrm{N}$-contents have been achieved. Analysing the phenol adsorption test at low phenol concentration (see Fig. 3), these high N-content carbons perform somewhat lower than the commercial AC.

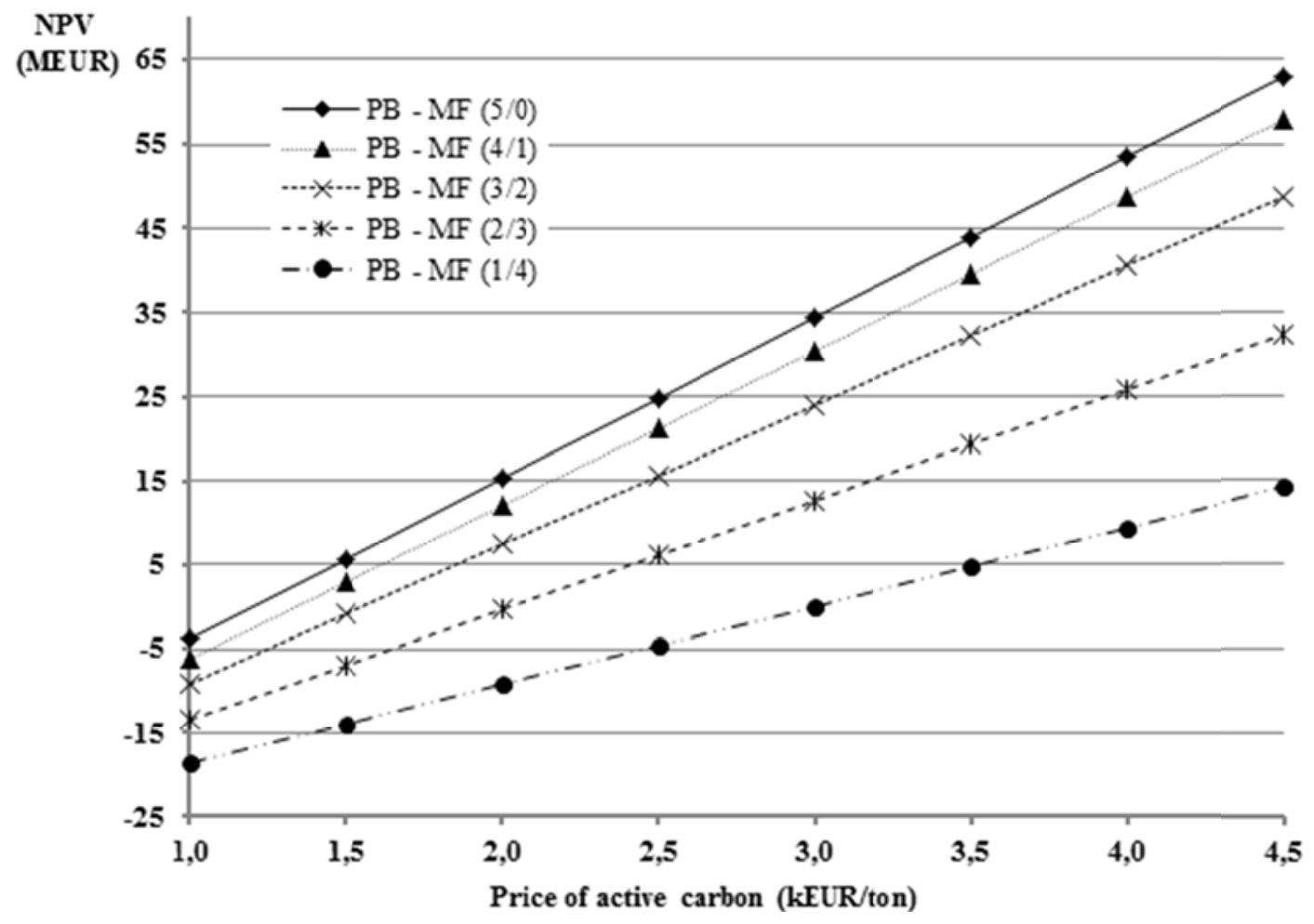

Figure 6 . NPV for a $2 \mathrm{t} / \mathrm{h}$ waste processing facility

Nevertheless, at higher phenol concentrations better performances and thus a higher value could be obtained [22]. It is thus necessary to further investigate other concentrations, target molecules, char characteristics and activation routes to thoroughly judge the economic feasibility of the different mixing ratios. 


\section{Economies of scale}

Another important factor determining the profitability of the process is the processing capacity. As a consequence of the economies of scale, which are incorporated in the total equipment cost equation, doubling the processing capacity augments the total capital investment with only $57 \%$. The total expenditure with only $36 \%$ to $53 \%$ and the break-even selling price decreases on average with $22.5 \%$ to $25.9 \%$ (compare Fig. 4 [1 t/h] with Fig. $6[2 \mathrm{t} / \mathrm{h}])$.

\section{Monte Carlo sensitivity analysis}

The economic viability of the AC production facility, i.e. the calculated NPVs, is also dependent on the accuracy of the predicted variables of the base case. Nevertheless some of these values are uncertain by definition, additionally other variables might strongly influence the NPV if their value changes slightly.

In order to investigate the effect of possible changes of the variables on the NPV a Monte Carlo sensitivity analysis is performed. Ten variables are selected and listed below:

- Total Capital Investment

- Electricity Cost

- Water Cost

- Delivered feed cost

- Discount rate

- Liquid nitrogen cost

- Char output

- AC output

- Staff cost / shift

- Annual working hours facility

The selected variables are now allowed to change with $10 \%$ above or below their initial value following a triangular distribution (characterized by a most likely, a minimum and a maximum value). Monte Carlos simulation calculates numerous (10000 per ratio) NPVs, for which in each run of the simulation a random value for each variable is drawn from the triangular distribution.

The minimum selling prices in order to guarantee a $95 \%$ chance on a positive NPV are calculated from the NPVs distributions. This distribution for a $1 \mathrm{t} / \mathrm{h}$ processing plant is characterized by the mean with their respective standard deviations as shown in Fig. 7. In the successive range $[\mathrm{PB}-\mathrm{MF}(5 / 0) \rightarrow \mathrm{PB}-\mathrm{MF}(4 / 1)]$ the minimum selling prices are respectively $2.0 \mathrm{kEUR} / \mathrm{t}, 2.2 \mathrm{kEUR} / \mathrm{t}, 2.5 \mathrm{kEUR} / \mathrm{t}, 3.1 \mathrm{kEUR} / \mathrm{t}, 4.5 \mathrm{kEUR} / \mathrm{t}$. These are somewhat higher than defined in the base case (Table 4). The results indicate that in the $2.0 \mathrm{kEUR} / \mathrm{t}$ to $2.5 \mathrm{kEUR} / \mathrm{t}$ price range no supplementary ratios are rejected compared to the base case. At the expected selling price of $2.0 \mathrm{kEUR} / \mathrm{t}$ only the AC produced from pure PB is profitable in order to guarantee a $95 \%$ chance on a positive NPV. The mean NPV calculated for the Monte Carlo simulation at this price is 3,5 MEUR.

Nevertheless, the same considerations (gate fee, $\mathrm{N}$-content and economies of scale) as in the base case need to be taken into account to analyse these results. 


\begin{tabular}{|c|c|c|c|c|c|}
\hline $\begin{array}{l}\text { NPV } \\
\text { (kEUR) }\end{array}$ & & & & & \\
\hline 25.000 & & & & & \\
\hline 15.000 & & & & & \\
\hline 5.000 & & & & & \\
\hline-5.000 & & & & & \\
\hline-15.000 & & & & & \\
\hline 1000 FUR & $\mathrm{PB}-\mathrm{Mr}(1 / 4)$ & $\mathrm{PB}-\mathrm{MF}(2 / 3)$ & & PD - MIF (4/1) & PD - MI (J/0) \\
\hline 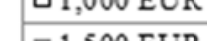 & -13.390 & -10.753 & & & -5.985 \\
\hline$=1,500$ EUR & -11.048 & -7.479 & -4.491 & -2.511 & -1.216 \\
\hline$\because 2,000$ EUR & -8.707 & -4.206 & -355 & 2.063 & 3.553 \\
\hline "2,500 EUR & -6.365 & -933 & 3.780 & 6.637 & 8.322 \\
\hline $\mathrm{L}: 3,000$ EUR & -4.024 & 2.341 & 7.916 & 11.212 & 13.092 \\
\hline$=3,500 \mathrm{EUR}$ & -1.682 & 5.614 & 12.052 & 15.786 & 17.861 \\
\hline 4,000 EUR & 659 & 8.888 & 16.187 & 20.361 & 22.630 \\
\hline $4,500 \mathrm{EUR}$ & 3.001 & 12.161 & 20.323 & 24.935 & 27.399 \\
\hline
\end{tabular}

Figure 7. NPV distribution

Finally, the average (normalized by the standard deviation of the output and the standard deviation of the input as defined in[13]) sensitivity of the NPV (Fig. 8) to the ten selected variables is determined. A positive value means that the NPV increases and a negative value means that the NPV decreases by an increase in the variable. The char and $\mathrm{AC}$ yields are almost independent of the ratio and are on average the most determining factors. The total annual hours of production is on average the third most important factor. The sensitivity of this variable increases by an increase of the selling price and by an increase in the share of PB. The Total Capital Investment (fourth most important factor) closely follows the sensitivity of the latter. The sensitivity increases by an increase in the share of MF and decreases as the selling price increases. The other variables have a negative sensitivity and are almost negligible compared to first four variables, except for the discount rate. 


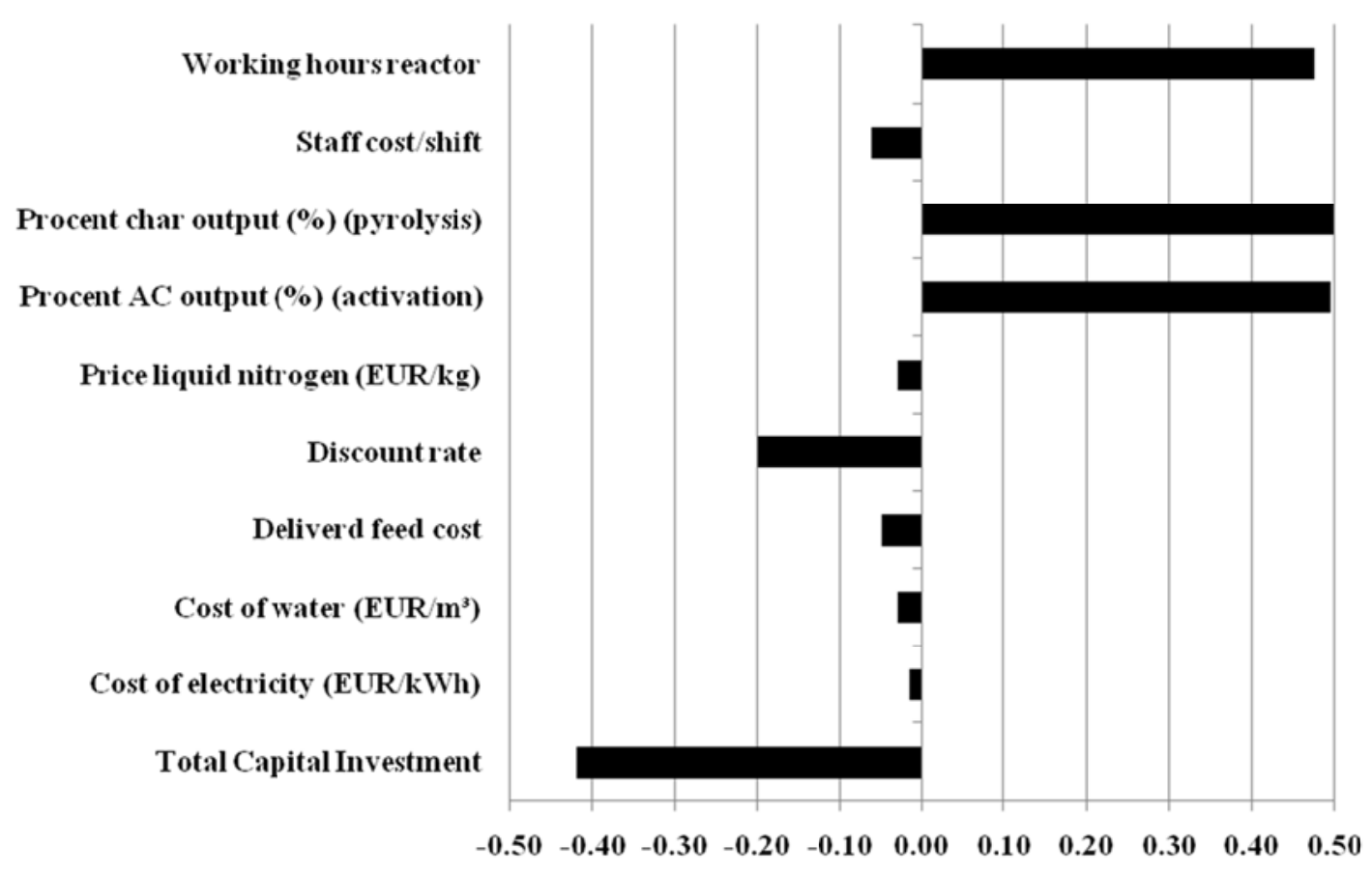

Figure 8 . Average sensitivity for a $1 \mathrm{t} / \mathrm{h}$ processing facility

\section{CONCLUSION}

To evaluate the feasibility of an AC production facility which processes MF and $\mathrm{PB}$ waste, pyrolysis and steam activation experiments have been carried out. Starting from five different blends of $\mathrm{PB}$ and $\mathrm{MF}$ waste, enhanced $\mathrm{ACs}$ with a nitrogen content ranging from $2.24 \mathrm{wt} \%$ up to $14 \mathrm{wt} \%$ are obtained. Pure PB yields the highest amount of AC (22 wt $\%$ ). The quality of the produced AC (steam activated) is determined by low concentration batch adsorption experiments for the removal of phenol from aqueous solutions (starting from $100 \mathrm{ppm}$ ).

Based on the obtained results and a feasibility model (with a rather pessimistic scenario: e.g. first plant cost) previously developed [13], really encouraging results are obtained for a profitable production of $\mathrm{AC}$ and scaling up the research. It is thus necessary to further investigate other concentrations, target molecules, char characteristics and activation routes to thoroughly judge the economic feasibility of the different mixing ratios and obtain higher AC qualities.

The economic feasibility depends largely on the annual working hours, char and AC yield, the product quality and the total capital investment.

\section{NOMENCLATURE}

$\begin{array}{ll}\text { PB } & \text { Particle board } \\ \text { MF } & \text { Melamine formaldehyde } \\ \text { MUF } & \text { Melamine urea formaldehyde } \\ \text { AC } & \text { Activated Carbon } \\ \text { NPV } & \text { Net present value } \\ \mathrm{T} & \text { Life span of the reactor }(20 \text { years }) \\ \mathrm{I}_{0} & \text { Initial total capital investment in year zero } \\ \mathrm{CF}_{\mathrm{n}} & \text { Cash Flows generated in year } \mathrm{n}\end{array}$




i
R
E
$\mathrm{t}$
$\mathrm{D}$
TGA
DTA
$Y_{\text {char }}$
Qfeed input pyrolysis $^{\text {f }}$

\section{FUNDING}

This research received no specific grant from any funding agency in the public, commercial, or not-for-profit sectors.

\section{REFERENCES}

1. Demirbas, A., Waste management, waste resource facilities and waste conversion processes, Energy Convers. Manage., 2011. 52(2): p. 1280-1287. (http://dx.doi.org/10.1016/j.enconman.2010.09.025)

2. Daian, G. and Ozarska, B., Wood waste management practices and strategies to increase sustainability standards in the Australian wooden furniture manufacturing sector, Journal of Cleaner Production, 2009. 17(17): p. 1594-1602. (http://dx.doi.org/10.1016/j.jclepro.2009.07.008)

3. Dornburg, V. and Faaij, A.P.C., Optimising waste treatment systems - Part B:

Analyses and scenarios for The Netherlands, Resources Conservation and

Recycling, 2006. 48(3): p. 227-248.

(http://dx.doi.org/10.1016/j.resconrec. 2006.02.002)

4. Dornburg, V., Faaij, A.P.C., and Meuleman, B., Optimising waste treatment systems - Part A: Methodology and technological data for optimising energy production and economic performance, Resources Conservation and Recycling, 2006. 49(1): p. 68-88. (http://dx. doi.org/10.1016/j. resconrec.2006.03.004)

5. BFM, L. Wood waste recycling in furniture manufacturing - a good practice guide, 2003 [cited 2011 May 4]; Available from: http://www.bfmenvironment.co.uk/images/wood\%20waste\%20recycling.pdf.

6. Bromhead, A. Benchmarking wood waste combustion in the UK furniture manufacturing sector, 2005 [cited 2011 April 5]; Available from: http://www.bfmenvironment.co.uk/images/BFM\%20Wood $\% 20$ combustion $\% 20 \mathrm{ben}$ chmarking\%20-\%20full1.pdf.

7. BFM, L. Evaluaton of the market development potential of the waste wood and wood products and reuse sector, 2004 [cited 2011 May 5]; Available from: www.bfmenvironment.co.uk/.../Wood\%20market\%20development.pdf

8. Federation, E.P. Market information, 2011 [cited 2011 April 11]; Available from: http://www.europanels.org/main_mi.html.

9. Girods, P., Dufour, A., Rogaume, Y., Rogaume, C., and Zoulalian, A., Comparison of gasification and pyrolysis of thermal pre-treated wood board waste, J. Anal. Appl. Pyrolysis, 2009. 85(1-2): p. 171-183. (http://dx. doi.org/10.1016/j.jaap.2008.11.014)

10. Girods, P., Rogaume, Y., Dufour, A., Rogaume, C., and Zoulalian, A., Low-temperature pyrolysis of wood waste containing urea-formaldehyde resin, 
Renewable Energy, 2008. 33(4): p. 648-654.

(http://dx.doi.org/10.1016/j.renene.2007.03.026)

11. Girods, P., Dufour, A., Rogaurne, Y., Rogaurne, C., and Zoulalian, A., Pyrolysis of wood waste containing urea-formaldehyde and melamine-formaldehyde resins, $J$. Anal. Appl. Pyrolysis, 2008. 81(1): p. 113-120.( http://dx.doi.org/10.1016/j.jaap.2007.09.007)

12. Girods, P., Dufour, A., Rogaume, Y., Rogaume, C., and Zoulahan, A., Thermal removal of nitrogen species from wood waste containing urea formaldehyde and melamine formaldehyde resins, J. Hazard. Mater., 2008. 159(2-3): p. 210-221. (http://dx.doi.org/10.1016/j.jhazmat.2008.02.003 PMid: 18359558)

13. Vanreppelen, K., Kuppens, T., Thewys, T., Carleer, R., Yperman, J., and Schreurs, S., Activated carbon from co-pyrolysis of particle board and melamine (urea) formaldehyde resin: A techno-economic evaluation Chem. Eng. J., 2011. 172(2-3): p. 835-846. (http://dx.doi.org/10.1016/j.cej.2011.06.071)

14. Vernimmen, P., Quiry, P., Le Fur, Y., Dallocchio, M., and Salvi, A., Corporate FINANCE Theory and Practice. sixth ed2005, Chicester: John Wiley \& Sons Ltd. 1032.

15. Kuppens, T., Cornelissen, T., Carleer, R., Yperman, J., Schreurs, S., Jans, M., and Thewys, T., Economic assessment of flash co-pyrolysis of short rotation coppice and biopolymer waste streams, Journal of Environmental Management, 2010. 91(12): p. 2736-2747. (http://dx.doi.org/10.1016/j.jenvman.2010.07.022 PMid:20724061)

16. Bridgwater, A.V., Toft, A.J., and Brammer, J.G., A techno-economic comparison of power production by biomass fast pyrolysis with gasification and combustion, Renew Sust Energ Rev, 2002. 6(3): p. 181-248. (http://dx. doi.org/10.1016/S1364-0321(01)00010-7)

17. Thewys, T. and Kuppens, T., Economics of willow pyrolysis after phytoextraction, Int. J. Phytorem., 2008. 10(6): p. 22. (http://dx. doi.org/10.1080/15226510802115141 PMid: 19260233)

18. Ochelen, S. and Putzeijs, B., Milieubeleidskosten - begrippen en berekeningsmethoden., 2008.

19. Devallencourt, C., Saiter, J.M., Fafet, A., and Ubrich, E., Thermogravimetry Fourier-Transform Infrared Coupling Investigations to Study the Thermal-Stability of Melamine-Formaldehyde Resin, Thermochim. Acta, 1995. 259(1): p. 143-151.

20. Srivastava, V.C., Swamy, M.M., Mall, I.D., Prasad, B., and Mishra, I.M., Adsorptive removal of phenol by bagasse fly ash and activated carbon: Equilibrium, kinetics and thermodynamics, Colloids and Surfaces A: Physicochemical Engineering Aspects, 2006. 272(1-2): p. 15-104. (http://dx.doi.org/10.1016/j.colsurfa.2005.07.016)

21. VLAREM-II. Besluit van de Vlaamse regering van 1 juni 1995 houdende algemene en sectorale bepalingen inzake milieuhygiëne, 2013; 17-02-2012:[Available from: http://navigator.emis.vito.be/milnav-consult/.

22. Girods, P., Dufour, A., Fierro, V., Rogaume, Y., Rogaume, C., Zoulalian, A., and Celzard, A., Activated carbons prepared from wood particleboard wastes: Characterisation and phenol adsorption capacities, J. Hazard. Mater., 2009. 166(1): p. 491-501. (http://dx.doi.org/10.1016/j.jhazmat.2008.11.047 PMid: 19128878)

23. Drage, T.C., Arenillas, A., Smith, K.M., Pevida, C., Piippo, S., and Snape, C.E., Preparation of carbon dioxide adsorbents from the chemical activation of ureaformaldehyde and melamine-formaldehyde resins, Fuel, 2007. 86(1-2): p. 10. (http://dx.doi.org/10.1016/j.fuel.2006.07.003)

24. Rivera-Utrilla, J., Sánchez-Polo, M., Gómez-Serrano, V., Álvarez, P.M., Alvim-Ferraz, M.C.M., and Dias, J.M., Activated carbon modifications to enhance 
its water treatment applications. An Overview, J. Hazard. Mater., 2011. 187(1-3): p. 23. (http://dx.doi.org/10.1016/j.jhazmat.2011.01.033 PMid:21306824)

25. Seredych, M., Hulicova-Jurcakova, D., Qing Lu, G., and Bandosz, T.J., Surface functional groups of carbons and the effects of their chemical character, density and accessibility to ions on electrochemical performance Carbon, 2008. 46(11): p. 14. (http://dx.doi.org/10.1016/j. carbon.2008.06.027)

26. Thewys, T. and Kuppens, T., Economics of willow pyrolysis after phytoextraction, Int. J. Phytorem., 2008. 10(6): p. 561-583. (http://dx.doi.org/10.1080/15226510802115141 PMid: 19260233)

27. Budaeva, A.D. and Zoltoev, E.V., Porous structure and sorption properties of nitrogen-containing activated carbon, Fuel, 2010. 89(9): p. 5. (http://dx.doi.org/10.1016/j.fuel.2010.04.016)

28. Seredych, M., Portet, C., Gogotsi, Y., and Bandosz, T.J., Nitrogen modified carbide-derived carbons as adsorbents of hydrogen sulfide, J Colloid Interface Sci, 2009. 330(1): p. 60-6. (http://dx. doi.org/10.1016/j.jcis.2008.10.022 PMid: 18990401) 